he reduced daily usage of nicotine gum to 16,12 , and 5 pieces, respectively, while using 3, 7 , and 14 pieces of placebo gum. During week 6 , he used no nicotine gum intake and averaged 17 pieces of placebo gum per day. During week 7 the 19 pieces of gum he used were divided between placebo gum and bubble gum. By week 8 and at the six-month follow-up he was using only bubble gum. We confirmed that he was not smoking (CO levels were negligible) and that nicotine gum use had been eliminated as planned (cotinine levels were 375,66 , and $0[<20] \mathrm{ng} / \mathrm{ml}$ at weeks 2,6 , and 32 , respectively).

In this case a simple procedure enabled a patient to achieve abstinence from nicotine gum without adverse effects such as resuming cigarette smoking or nicotine withdrawal symptoms. Whereas occasional use of nicotine gum may be required long-term to prevent relapse to tobacco use in some people abstinence from any source of nicotine is the target recommended by the manufacturers of nicorette and that is what gum users and those treating them aim for. ${ }^{1,2}$ Our experience suggests that it might be useful for a placebo (nicotine) gum to be made commercially available.

Department of Psychiatry

and Behavioral Sciences,

Johns Hopkins University

School of Medicine,

Baltumore, Maryland 21205, USA;

and Addiction Research Center,

National Institute on Drug Abuse,

Baltumore
H. RICHARD WARANCH

JACK E. HENNINGFIELD

MARGARET EDMUNDS
1. Ockene JE. The pharmacologic treatment of tobacco dependence. In: Proceedings of the World Congress. Nashua, New Hampshire: Puntan Press, 1986.

2. Hughes JR. Problems of nicotine gum. In: Ockene JK, ed. The pharmacologic treatment of tobacco dependence Proceedings of the World Congress November, 1985). Cambridge, Massachusetts: Instutute for the Study of Smoking Behaviour and Policy, 1986.

3 Hughes JR, Hatsukami D. Physical dependence on nicotine gum: a placebo substitution trial. FAMA 1986; 255: 3277-79

4. West RW, Russell MAH. Effects of withdrawal from long-term nicotine gum use. Psychol Med 1985; 15: 891-93

5. Benowitz NL. The use of biological fluid samples in assessing tobacco smoke consumption. In. Grabowsk1 J, Bell CS, eds. Measurement in the analysis and treatment of smoking behaviour Washington, DC: US Government Printing Office, 1983: 6-26.

6. Jarvik ME, Hennungfield JE Pharmacologic treatment of tobacco dependence. Pharnacol Blochem Behav (in press).

\section{FORMS OF COCAINE AND PSYCHIATRIC SYMPTOMS}

SIR,-Dr Honer and colleagues (Aug 22, p 451) report an increase in psychosis and violence among users of "crack" cocaine compared with users of other forms of cocaine. They separated crack users from "freebase" users, implying that crack and freebase represent different forms of cocaine. This is untrue, of course, because crack and freebase are chemically identical, consisting of alkaloidal cocaine; also, both crack and freebase are typically ingested by smoking.' "Therefore the differences they found between their crack and freebase users most likley reflected differences in other factors such as dose or demography. Although Honer et al concede these possibilities, they present no data to clarify the issue.

Contrary to the assertion by Honer and colleagues that "symptoms among users of different forms of cocaine have not been compared", we have reported such comparisons among 100 cocaine users presenting to a psychiatric emnergency room. ${ }^{2}$ Our patients were divided by their preferred method of ingestion into intranasal $(n=16)$, intravenous $(n=28)$, and smoking $(n=56)$ groups. We found no significant differences between the three groups in psychotic symptoms (persecutory delusions and auditory, visual, or tactile hallucinations). ${ }^{2}$ Although not previously reported, our data also failed to reveal any significant difference between the three groups in violence, defined as physical harm to self or others. $19 \%$ of the intranasal group, $33 \%$ of the intravenous group, and $36 \%$ of the smoking group reported violence. Further analysis of our data showed that cocaine users with psychotic or violent symptoms used more cocaine over more days in the month before interview than users without these symptoms (table).

Our data support a model ${ }^{3}$ suggesting that psychotic and violent symptoms from cocaine are associated with frequency of use and
PATTIEN OF COCAINE USE AMONG COCAINE PATILNTS WITH AND WITHOUT' SYMPTOMS OF P'SYCHOSIS AND VIOLENCE*

\begin{tabular}{l|c|c|c|c}
\hline \multirow{2}{*}{$\begin{array}{c}\text { Cocaine use } \\
\text { in past month }\end{array}$} & \begin{tabular}{c}
$|c|$ \\
Yes \\
\cline { 2 - 5 }
\end{tabular} & $\begin{array}{c}\text { No } \\
(\mathrm{n}=66)\end{array}$ & $\begin{array}{c}\text { Yes } \\
(\mathrm{n}=29)\end{array}$ & $\begin{array}{c}\text { Vo } \\
(\mathrm{n}=62)\end{array}$ \\
\hline $\begin{array}{l}\text { No of days } \\
\text { Weight }(\mathrm{g})\end{array}$ & $14 \cdot 0(113)$ & $4 \cdot 3(5 \cdot 9) \dagger$ & $16 \cdot 4(12 \cdot 2)$ & $8.9(9 \cdot 7) \ddagger$ \\
\hline
\end{tabular}

Findings given as mean (SD).

$\star_{n}=91$, because 9 of the 100 patients had missing data.

Comparison between groups (two-tailed t test)- $t \mathrm{p}<0001$ and $\ddagger \mathrm{p}<001$

dose, irrespective of the form of cocaine used or the method of ingestion. Cocaine smokers do tend to develop addictive patterns of use at a faster rate than users of other ingestion methods, ${ }^{1}$ and the addictive patterns are marked by more frequent use and the consumption of higher doses. Nevertheless, users of any form of cocaine, ingested by any method, can suffer adverse effects ranging from psychosis and violence to death. ${ }^{4}$ This is the critical message for emergency-room personnel and their cocaine-using patients.

Department of Psychiatry,

University of Michigan Medical Center,

Ann Arbor, Michigan 48109, USA

KIRK J. BROWER

FREDERICK C. BLOW

THOMAS P. BERESFORD

1. Siegel RK. Cocaine smoking: Nature and extent of coca paste and cocane freebase abuse. In: Washton AM, Gold MS, eds. Cocaine: a clinician's handbook. New York: Guilford Press, 1987-175-91.

2 Brower KJ, Hierholzer R, Maddahan E. Recent trends in cocaine abuse in a VA psychatric population. Hosp Commumty Psychtatry 1986; 37: 1229-34.

Post RM Cocaine psychoses. a continuum model. Am f Psychzatry 1975; 132: 225-31

4. Wetli CV, Fishbain DL. Cocaine-induced psychosis and sudden death in recreatuonal cocane users. F Forensic Sci 1985; 30: 873-80.

\section{PENICILLIN-RESISTANT BORRELIA ENCEPHALITIS RESPONDING TO CEFOTAXIME}

SIR,-The established treatment of neurological Lyme disease is high-dose intravenous penicillin. ${ }^{1}$ In cases presumed resistant to penicillin, ceftriaxone is effective. ${ }^{2}$ Because ceftriaxone is not available in the UK and other Western European countries we were prompted to use intravenous cefotaxime in a patient who was positive for Borrelia burgdorferi antibodies and in whom no response had been obtained with penicillin.

A previously healthy 52 -year-old man was admitted in June, 1987, after he had been found wandering in his garden, confused and restless. He was irritable and disoriented in time and place and had difficulty in concentration and a poor memory. His temperature was $37.8^{\circ} \mathrm{C}$; he had no other physical abnormality. There was no history of tick-bite, cutaneous eruption, or any neurological or other systemic signs. Cerebrospinal fluid (CSF) contained increased protein $(0.62 \mathrm{~g} / 1)$, normal glucose, and 3 leucocytes $/ \mu 1$. Culture for fungi, bacteria (including mycobacteria), and viruses were negative. A computerised tomographic brain scan (CT) was normal. Electro-encephalogram (EEG) showed generalised slow-wave dysrhythmia in the delta range. He was treated with intravenous acyclovir, $1 \mathrm{~g}$ daily, in divided doses for 7 days for possible herpes encephalitis but without response. Herpes simplex antibody titre was not significantly increased during the illness. An indirect immunofluorescence test for antibodies to $B$ burgdorfer 1 week after admission showed a serum IgG titre of 512 , which was confirmed 2 weeks later when the IgG titre was 1024. IgM titres were negative in both samples. No borrelial antibodies were found in CSF. Auto-antibody Venereal Disease Research Laboratory and Treponema pallidum haemagglutination assays were negative. 3 weeks after admission he was treated with intravenous benzylpenicillin, $20 \mathrm{MU}$ daily in divided doses for 10 days without response. 4 days after the end of the course of penicillin he had a generalised seizure which was controlled with carbamazepine. At this stage CSF contained increased protein $(0.68 \mathrm{~g} / 1)$, normal glucose, and 2 leucocytes $/ \mu \mathrm{l}$. CT was normal and the IgG specific antibody titre for $B$ burgdorferi remained at 512. EEG showed slow-wave dysrhythmia.

8 weeks after admission he was started on intravenous cefotaxime, $2 \mathrm{~g}$ three times daily, and prednisolone, $40 \mathrm{mg}$ daily. 